\title{
A Conceptual perspective on the impact of Micro Finance on Women Empowerment
}

\author{
N.B.Sikivahan, V.M.Ponniah
}

\begin{abstract}
Equitable growth is a very important factor for the development of any nation. Traditionally, women in India have been not so privileged with regard to access for credit and financial services. The formal financial sector predominantly lends to the male populace and sometimes the women end up with challenges for credit. Globally, $\sim 65 \%$ of people under poverty are women. Hence, this makes it more pertinent to provide credit to women to ensure that there is equitable growth. Microfinance achieves to bridge this gap by providing women clients with affordable credit to enable them to grow.

This conceptual study is to understand the impact of Microfinance on women empowerment internationally amongst developing nations and the impact of Microfinance on women empowerment in India. This study revolves around understanding of key research done globally on important variables such as income savings on the economic empowerment and social empowerment variables such as impact of family decision making \& freedom to state a few.
\end{abstract}

Index Terms: Microfinance, Women Empowerment, Self help group, Government policy

\section{INTRODUCTION}

Microfinance supplies credit to poor and low income population in order to ensure that the poor and low income people have access to gainful employment through provision of micro credit. Since the commencement of Microfinance in the 1980's in India, Microfinance has been instrumental in addressing the overall developmental issues. In addition to supporting and providing credit, Microfinance supports in skill based training as well as providing information on best practices and thereby uplift the poor and needy people (Shahidur Khandkar, 2000).

Particularly in India, there has been a traditional gender bias. Women are traditionally homemakers and support their spouses in running the home. However, it has been observed basis studies that homes where women who are empowered display a better sense of security (Quisumbing AR, Brown LR, Feldstein HS, Haddad L \& Pena C. 1995).

Women with a better decision making power also displayed higher empowerment rates. Empowerment can be broadly categorized into three elements:

a) Confidence for women to take decisions, follow goals and express their thoughts without fear from retributions

b) Societal structures that aspects women's lives

c) Resources, which provide women with the resources such as education, capital credit, societal respect (

Revised Manuscript Received on July 05, 2019.

N.B.Sikivahan, School of Management, SRM Institute of Science and Technology, Kattankulattur, Chennai, Tamizhnadu, India.

Dr.V.M.Ponniah, School of Management, SRM Institute of Science and Technology, Kattankulattur, Chennai, Tamizhnadu, India.
Eerdewijk A, Wong F, Vaast C, Newton J, Tyszler M, Pennington A. 2017).

\section{Microfinance and Women Empowerment - Reflections of International Studies}

The primary role for women in the economy was considered to be that of reproduction. The government's role was to focus on maternal and child health. In addition to maternal health, Governments also focused on family planning, immunization nutrition and basic healthcare. While Governments focused on maternal health, microfinance focused on women empowerment across economic, social and skill empowerment. The primary focus of microfinance for women empowerment is to encourage women to play a productive role in their respective homes. Microfinance encourages women to support the household in generating income and thereby support their spouses in providing contribution towards the household expenditure. In addition to supporting by providing an income for the family, women are also encouraged to support their households during emergencies and thereby making the women equal parts of the household.

Studies carried on across various countries provide a clear co-relation between microfinance and the income bearing capacity of women. Various analyses clearly highlight the fact that microfinance enables women to be more confident and secure and empowers them across all fronts be it economical, social or psychological.

Research has been conducted in Ghana that microfinance institutions support the client's requirements and make a profound impact on providing credit and working capital to women. The women were able to support their families for the basic needs and also supporting in family decision making (Mercy Asamoah*, Franklin Manu Amoah, 2015).

Studies carried out in Tanzania have proved that participation of women in micro finance had provided them with better source of income and savings. Participation in microfinance had also improved their contribution to their family's decision making and better self esteem among the women participants. In addition, the women participants also exhibited a higher sense of freedom and mobility (Mushumbusi Paul Kato, Jan Kratzer).

There have been researches carried out in Bangladesh to understand the relationship between microfinance and women empowerment. The research depicted a strong relationship between management skills and women participants. There was significant improvement in the women's entrepreneurial skills post availing credit from microfinance. Availability of micro credit empowers the women to commence small businesses and thereby supplement the family income 
(Afrin, Islam and Ahmed (2010).

There was another study conducted in Bangladesh on identifying the relationship between microfinance and women empowerment. The study identified that there was a positive impact on the generation of income, family planning, household expenditure including children's education, general family expenses and thereby improved the stature of women in family and society (Syed Masud Ahmed, Mushtaque Chowdhury (2001)

There has been a study conducted with a global data set with variables from 70 countries and identified that microfinance with a larger proportion of women borrowers had better risk for payment profile and write off rate (D'Espallier, Bert \& Guérin, Isabelle \& Mersland, Roy, 2011.

A research conducted by Yunus mentions that family planning adoption was double the rate for Grameen bank beneficiaries as against the national average in Bangladesh. These researches deduced a higher adoption family planning rates by microfinance beneficiaries as against people who were not microfinance beneficiaries.

Hence, it can be learnt from international studies that microfinance provides a great impetus to economic empowerment to the participants. It has been observed that even in developing nations there is a clear co-relation between impact of micro credit and the stature of women in the family and societal structures. In addition, the studies have clearly highlighted in social as well as psychological empowerment of beneficiaries.

\section{Microfinance and Women Empowerment in India - Government initiatives}

Economic Empowerment for all is one of the key objectives of the Government and therefore the Government has to take initiatives to ensure that equal opportunities are provided to all in the society. India, being primarily a patriarchal society, traditionally women have not been economically empowered. Hence, there is a requirement for the Government to provide policy level commitments to women. An understanding of current literature available points to the fact that Government of India has taken a lot of initiatives towards women empowerment. The Government of India has drafted a revised Women Empowerment Policy in 2016 i.e. "National Policy for Women 2016". As per the updated policy: "Empowerment of women is a socio political ideal envisioned in relation to the wider framework of women's rights. It is a process that leads women to realise their full potential, their rights to have access to opportunities, resources and choices with the freedom of decision making both within and outside home. Empowerment would be achieved only when advancement in the conditions of women is accompanied by their ability to influence the direction of social change gained through equal opportunities in economic, social and political spheres of life".

Research conducted across 15 major states in India studying six key empowerment indices covering demography, education, health, domestic violence, family economic support and societal awareness and respect. The outcome of the research presented the fact that Kerala and Tamilnadu were the Top 2 performing states with West Bengal and Uttar Pradesh at the bottom (Arundhati Chattopadhyay, 2012).

Other studies carried out highlighted the fact that the multiple schemes provided by Government for women empowerment was generic and did not necessarily cater to the ground realities and the various diversities in the Indian society. India is also a country to multiple castes and political affiliations across the states and hence there is a challenge in structuring schemes as it is a challenge to cater to domestic requirements (Lahiri-Dutt \& Samanta 2006).

Another research undertaken pointed out to an increased contentment amongst the women beneficiaries on the benefits for health from the Government run schemes. The research also pointed to a clear intertwined relationship between economic, social and political empowerment. If there has to be a success for women empowerment there has to be a combined effort across economic, social and political empowerment. If there is betterment in couple of the dimensions with one of them being a failure, then the impact of the other two areas are minimal (Singh R.H., \& Singh D.N. (2012).

It can be inferred from current available literature that Government of India has taken several policy level initiatives to ensure that women empowerment. However, given the nature of India, there is always a lot more to be done and achieved to attain women empowerment. Hence, it makes a perfect case of public and private collaboration to ensure that micro credit is provided to women beneficiaries thereby enabling them to succeed in their endeavours.

\section{IMPORTANT VARIABLES FOR UNDERSTANDING THE IMPACT OF MICROFINANCE ON WOMEN EMPOWERMENT}

Women empowerment is a very holistic aspect and is a combination of access to availability of finance as well as social and psychological empowerment that enables them to be more confident in carrying themselves in their homes and societies.

Studies and researches in India have pointed divergent indices for women empowerment across states because of the geo political diversity across Indian states. The outcome of the research pointed out that states of Goa, Gujarat, Mizoram, Arunachal Pradesh, Sikkim, Kerala, Karnataka and Tamilnadu displayed a higher sense of freedom of mobility as against the other states (Gupta and Yesudian, 2006).

Analysis of existing conditions have highlighted that the presence of NGO's and Institutions have played a catalyst role in ensuring that women beneficiaries who have formed groups are successful in their endeavours. It is observed that there are initial struggles once the SHGs are formed and with the support of NGO's and other Institutions manage their group through regular meetings and discussions and thereby ensure to have an income from the credit received. Hence, it can be deduced that NGOs and Institutions play a crucial role in ensuring economic empowerment (Lalita and Prasad, 2009).

Another study had an observation that beneficiaries with similar socio economic conditions had a very parallel impact of the self confidence and self esteem levels and also the personal skills sets of beneficiaries (Dadich, 2001).

One of the critical factors for study of the impact of microfinance is on the tenure of participation of the women beneficiaries. Various researches have highlighted 
the fact that the term and frequency of availing of micro credit has an effect on the holistic impact of women empowerment. There has been a direct co-relation between the decision making power of women beneficiaries and the tenure of participation in microfinance (Panda, 2009).

It has been observed amongst studies that SHGs generate a sense of savings motive amongst beneficiaries and beneficiaries can leverage the savings to support their familes during emergencies. The SHGs are able to provide basic banking services to their members and it will be very effective if there are co-operative linkages between banks and SHGs (Satish, 2005).

Some of the other advantages of microfinance are also on the softer aspects such as self confidence and self reliance and self sufficiency. Hence, the steps taken for micro finance has a significant improvement in the beneficiaries and directly contributes to rural development (Kulshresta 2000).

Another study pointed out that the savings through SHGs enabled the women beneficiaries to develop their confidence and thereby progress to get access to direct banking facilities thereby enabling them access for organized and better credit facilities. It was also observed in the same study that higher savings in SHGs also resulted in higher productive assets (Rajasekhar, 2004).

A research carried out in Kerala inferred that access to micro credit and micro entrepreneurship enabled employment for the beneficiaries. It was also identified that if there was no access provided for micro credit the beneficiaries would have been largely unemployed. Hence, the access to micro credit has enabled the beneficiaries to avail employment (full time or part time). It was observed that there was employment generated for up to 20 days in a month (Raghavan, 2006).

\section{CONCLUSION}

It is clear from the studies that while the Government has come forward and provided many schemes for upliftment of women and their empowerment, there have been also many private agencies providing credit facilities to the women beneficiaries. While a lot has been carried out by public and private agencies, there is a lot to be carried out and there is potential for increasing the impact of microfinance on women empowerment. It has been very clearly observed that leverage of micro credit provides a platform for women beneficiaries for economic empowerment through increase in income, savings as well as improvement in personal well being through better skill sets. There has been a clear inter relation between the economic empowerment, social empowerment and psychological empowerment of beneficiaries.

The impact of microfinance has clearly been observed in increasing the self confidence and self esteem of the beneficiaries. The impact of self confidence of the beneficiaries has been directly felt on the households of the beneficiaries. There is increased respect of the beneficiaries at their homes and society at large. There has been greater freedom observed amongst the beneficiaries to express themselves at life better and not be constrained in life. Various studies also clearly point out the importance of SHGs in ensuring women empowerment and a clear linkage between the tenure of microfinance to the extent of women empowerment.

Thus, introduction of microfinance and access to micro credit has an impact in the income of the participants, increase women empowerment as well as improve the social and psychological empowerment.

\section{REFERENCES}

[1] Ackerley, B.A., Testing the tools of development: credit programmers, loan involvement and women's empowerment, IDS Bulletin, 26(3) (2001).

[2] Afrin, Islam and Ahmed Micro Credit and Rural Women Entrepreneurship Development in Bangladesh: A Multivariate Model, Journal of Business and Management, 16(1) (2010).

[3] Ana, Mar, Studying Group Dynamics-An analysis of Microfinance impacts on poverty in Peru, London: University of London (2002).

[4] Chattopadhyay, Arundhati, Women and Entrepreneurship", Yojana, 49, 27-33 (2005).

[5] Chiranjeevulu, T., Empowering Women through Self Help Groups: Experiences in Experiment, Kurukshetra, 51(5), March 16-19, 2003.

[6] Dadhich, C. L., Micro Finance - A Panacea for Poverty Alleviation: A Case Study of Oriental Grameen Project in India, Indian Journal of Agricultural Economics, V56 (3), 419-43 (2001).

[7] Datar, S. M.,Epstein, M.J., \& Yuthas, K., In Microfinance clients must come first. Stanford Social Innovation Review, 6(1), 38-45 (2007). Retrieved from http:// www.ssireview.org/ images/articles/ 2008WI_ feature_datar_Epstein _ yuthas.pdf

[8] D'Espallier, Bert \& Guérin, Isabelle \& Mersland, Roy, Women and Repayment in Microfinance: A Global Analysis, World Development, Elsevier, 39(5), 758-772 (May 2011)

[9] Debadutta Kumar Panda, Assessing the Impact of Participation in Women Self-help Group-based Microfinance, International Journal of Rural Management, 5(2), 197-215.

[10] Eerdewijk A, Wong F, Vaast C, Newton J, Tyszler M, Pennington A., White Paper on "A Conceptual Model of Women and Girls Empowerment” Amsterdam : Royal Tropical Institute (KIT), Radboud University (2017).

[11] Khandkar \& Shahidur .R. "Savings, Informal Borrowings and Microfinance”, Bangladesh Development Studies, 26( 2\& 3) (2000).

[12] Kamla Gupta \& Princy Yesudian Evidence of women's empowerment in India: a study of socio-spatial disparities, Geo Journal, 65(4), 365-380 (May 2006)

[13] Lalitha K., and Prasad G., Empowerment of Women: DWCRA Programme, Southern Economist, 47(23\&24), 13-16 (2009).

[14] Lakshmi, R. Kulshreshta, "Microfinance : The New Development Paradigm for Rural Women", Kurukshetra, 49(2), 22-25 (November 2000).

[15] Lahiri-Dutt \& Samanta, Micro-credit initiatives for equitable and sustainable development: Who pays? World Development, 27(1), 67-82 (2006)

[16] Mercy Asamoah*, Franklin Manu Amoah, Microcredit Schemes: A Tool for Promoting Rural Savings Capacity among Poor Farm Families: A Case Study in the Eastern Region of Ghana, Open Journal of Social Sciences, 3, 24-30 (2015).

[17] Mushumbusi Paul Kato , Jan Kratzer ACRN Journal of Entrepreneurship Perspectives, 2(1), 31-59 (Feb. 2013).

[18] Patnaik, C.P., Micro finance role in poverty alleviation and economic growthA study in Gajapati district, International Journal of Social sciences and Interdisciplinary Research, 1(3) (March 2012).

[19] Puhazhendi, V. and Badatya, K.C., SHG-Bank linkage programme for Rural Poor: An Impact Assessment, Paper presented at the Seminar on SHGbank Linkage Programme at New Delhi on 25th and 26th November.

[20] Quisumbing AR, Brown LR, Feldstein HS, Haddad L \& Pena C., Women: The key to food security. International Food policy research Institute, USA (1995).

[21] Rajasekhar D., Microfinance and poverty alleviation: Issues relating to NGO's programmes in south India. Working paper, 146, Institute for social and economic change. Bangalore (2004).

[22] Raghavan, V.P., Livelihoods and Empowerment: The Kudumbashree Projects in Kerala, India - A New Paradigm of Participatory Economy. Paper presented at 13th conference of the International Association for the Economics of Participation on 13-15th July 2006 at Mondragon University, Spain

[23] Syed Masud Ahmed, Mushtaque Chowdhury, Micro Credit and Emotional Well being: Experience of poor rural women from Matlab, 
A Conceptual perspective on the impact of Micro Finance on Women Empowerment

Bangladesh, World Development, 29(11), 1957 - 1966 (2001).

[24] Satish P, Mainstreaming of Indian Microfinance, Economic and Political Weekly, 40(17), 1731-1739 (Apr. 23-29, 2005).

[25] Singh R.H., \& Singh D.N., An Impact Assessment of Microfinance: A case study of socio economic empowerment of SHG members in Manipur (2012). In doi: handbook5.com/ a/an-impact-assessment -of-microfinance -a-case-study-ofw69074.html. 